\title{
Social Science Should Be a Process, Not a Bloody Shirt
}

\author{
Edward Muir, American Federation of Teachers, AFL-ClO*
}

ay Greene and Paul Peterson's
response to my December 1999
$P S$ article spills indignation over a
case I did not make while avoiding
my basic argument: Advocacy under
the banner of science is irresponsi-
ble when researchers have not con-
formed to the norms of their disci-
pline. Rather than wrestle with this
troubling issue, Greene and Peter-
son attack a straw man. They argue that I am attempting to "pillory, marginalize, and suppress the results of scholarly research," "ban" their paper, and institute a "rule" to benefit advocacy groups-such as the one I work for, but not the provoucher advocacy groups that fund and publicize their provoucher research. This is an invention of my position, but it does allow them to wave the bloody shirt of "academic freedom" before the professorial community in much the same manner that they chose to use science as a trope to legitimize opinions expressed in their 1996 Wall Street Journal article.

I argued that Greene and Peterson went beyond their evidence in their public writing on the Milwaukee voucher program. The subsequent research cited in my original article indicates the extent to which they overstated their policy prescriptions and underscored the questionable nature of both their significance testing and their controls for attrition bias. ${ }^{1}$ Greene and Peterson's actions and the controversy following their public announcement of their findings illustrate why political scientists should be rigorous when deploying their research to affect the

Edward Muir has been an associate in the research department of the American Federation of Teachers since 1997. He has been a member of the American Political Science Association since 1993. He is currently an investigator on the U.S. Department of Education's National Charter School Finance Study. policy debate. I did not and do not argue against academic freedom in pointing this out, but instead am arguing in favor of good science and its responsible use.

Greene and Peterson's claim that my argument is a proposal designed to favor advocacy groups is rather startling. They are no more strangers to advocacy groups than am I. Much of their research has been funded by voucher advocates and they have worked with advocacy groups to broadcast their results. ${ }^{2}$ Neither they nor I are unique in these affiliations. Many social scientists work for advocacy groups and many advocates work in academe. The dichotomy between advocates and academics is a false one-except in the minds of the public.

Research from the university is typically vested with a higher degree of credibility than research from advocacy groups because of the former's supposed apolitical and objective viewpoint. Most members of the general public assume that reports from the academy will have met appropriate scientific standards just because they are from the academy. The Greene and Peterson research is, in public debate, often referred to as the "Harvard research," not the "research supported by the Olin Foundation." This is because Harvard is a symbol of academic integrity. But Harvard, or any other university, only carries such symbolic value as a result of its faculty's normative commitment to standards in academic inquiry. Because privately funded research may carry a residual mystique of the ivory tower, it is all the more essential that academic researchers strive to meet social science standards when claiming the authority of social science in public debate.

To state this is not to argue against academic freedom. Nowhere did I suggest that Greene and Peter- son should have been prevented frm taking pen in hand to write op eds or other popular media pieces. I would defend any political scientist's right to advocate for causes that they espouse. Political scientists are, after all, citizens as well as professionals. But, when social scientists couch advocacy in science, their fidelity should to be to the norms of science. If it is demonstrably not, I believe their peers should criticize them. "Science" is a powerful symbol. A lay audience can easily take a reference to its trappings as a justification of its author's argument. For this reason, I question the practice of putting the cart of public advocacy based on research results before the horse of scientific discourse.

Greene and Peterson also quote me as writing "To present to the general public research that has not endured the scrutiny of peer review..., while all the time calling the work 'political science' is a challenge to the very nature of our enterprise as a community of scholars and citizens." The convenient ellipses allows them to equate their research with that of Robert Putnam, Frances Fox Piven, and my own colleagues. The sentence actually reads: "To present to the general public research that has not endured the scrutiny of peer review and whose statistical results have not been held to the standards established by the scientific community, while all the time calling the work "political science' is a challenge...." (Muir 1999, 764; italics added). It is here that the heart of my disagreement with Greene and Peterson over the irresponsible use of unvetted research can be found.

Putnam and Piven did not dress their theories in the trappings of science in an effort to legitimize their arguments. This is an important distinction and, again, Greene and Peterson's article in The Wall Street Journal is an example of why. By titling their piece "School Choice 
Data Rescued from Bad Science," Greene and Peterson explicitly

Research from the university is typically vested with a higher degree of credibility than research from advocacy groups because of the former's supposed apolitical and objective viewpoint.

called attention to their "scientific conclusions" and gave themselves the authority to declare that John Witte's evaluation "isn't just bad science it's actually harmful to the underprivileged children who most need the opportunities vouchers would provide." This play on the public's understanding of the term "science" to increase the perceived legitimacy of their findings could well be said to be "blinding." 3

Take, for example, Robert Putnam's "Bowling Alone" (1997). Imagine if, instead of an essay on social capital inspired by observing people bowling alone, Putnam had written that his scientific analysis of strikes and spares indicated that team bowling was inefficient. Then, what if he had argued that his social science showed that a tax on team bowling shirts should be used to discourage bowling team formation for the good of bowlers everywhere. Further, imagine that he had announced that because his research was based on a model that allowed him to be the first researcher to control for the fit of rented bowling shoes, it was better science than that of any other researcher who had examined the issue. In this hypothetical instance, I would argue that Putnam should submit his findings to an academic journal or an academic conference before submitting them to a major national newspaper or calling a press conference.

Judging from their response, Greene, Peterson, and I appear to agree that social scientists should participate in the public sphere. I believe, however, that we should take special care when speaking as social scientists, and that processes such as peer review are an appropriate source of that care. Greene and Peterson, however, seem to believe that care should be used except when it is inexpedient. They note that they did present their paper at an Annual Meeting of the American Political Science Association and received a heated retort from John Witte. I would agree with them that this constitutes a form of peer review, from which they could have gained valuable insights. But the conference was in September 1996, while their opinion piece was released in August, coinciding with then-presidential candidate Robert Dole's address advocating voucher programs and the Wisconsin court hearings on the future of the voucher program. If, as they all but do in note 4 of their preceding article, Greene and Peterson argue that scientific norms are something to be sacrificed for the sake of this type of expediency, then I must disagree with their argument.

Finally, Greene and Peterson state that I ignored John Witte's earlier studies of the Milwaukee voucher program and painted them as the first to write a nonpeerreviewed analysis of vouchers. They question why I have chosen to "demonize" them. ${ }^{4}$ The record on voucher experimentation in America goes at least as far back as the Alum Rock program in the early 1970s, and much ink had been shed, including some by Professor Witte, prior to 1996. I do not purport Greene and Peterson's to be the first unreviewed research report on vouchers. I chose to focus on their 1996 Wall Street Journal article because the subsequent controversies over the scientific validity of their work provide an object lesson as to why, in performing the important act of communicating results outside the small community of education policy researchers, responsibility should be the order of the day.

\section{Notes}

\footnotetext{
* The views expressed in this article are those of the author and not of the American Federation of Teachers.

1. In their response, Greene and Peterson take exception to my citation of Alex Molnar's recalculation of statistical significance tests from their Milwaukee research, using a self-effacing comment from Molnar. Molnar's calculations, however, are correct. John Witte also raised this point in 1996. It has been a source of controversy in Greene and Peterson's evaluations of the Ohio voucher program as well, leading Kim Metcalf to wonder if Greene and Peterson engage in "Advocacy in the Guise of Science" (Metcalf 1998). In their response to me, Greene and Peterson point out that the combined third and fourth year results of the children in their sample who had received vouchers was statistically
}

significant at conventional levels. This might be seen as a post hoc case of combining favorable analyses in order to increase the number of valid cases, and, hence, significance. It is also a case of examining "survivors" in a program that had $30 \%$ annual attrition and announcing that because they were healthy the program was a success. Yet, Greene and Peterson used these results to suggest that vouchers could close the blackwhite student achievement gap. Greene and Peterson also claim that Cecilia Rouse (1998) has "replicated" their findings. While it is true that Rouse replicated their approach in some models, it is also true that she followed John Witte's approach, which Greene and Peterson attack, in others. Also, Rouse did not apply the same standards as Greene and Peterson, or choose to conflate third-and fourth-year scores, or reach the same policy conclusions. The differences between the two works are at least as telling as the similarities.

2. The Olin Foundation funded the Milwaukee evaluation. Peterson has also received funding from the provoucher Harry and Lyme Bradley Foundation and the funders of private voucher programs that he evaluates. $\mathrm{He}$ has also worked with Clint Bolick's Institute for Justice to publicize his findings. In other work, Peterson has written of voucher advocates as reminiscent of "a small band of Jedi attackers, using their intellectual powers to fight the unified might of Death Star forces led by Darth Vadar [sic], whose intellectual capacity has been corrupted by the urge for complete hegemony." (Peterson 1990, 73).

3. Greene and Peterson assert that the use 
of the word 'blinded' in my original title is particularly "violent." While the title is apt, it is also little more than a play on the title of a popular, somewhat dystopian, 1980s love song: Thomas Dolby's "She Blinded Me With
Science." Such adaptations are something of a political science convention in and of themselves.

4. This characterization is particularly ironic given that Peterson has specifically compared John Witte's evaluation of the Milwaukee voucher program to the Eighth Circle of Hell in Dante's Inferno (Peterson and Noyes 1996).

\section{References}

Metcalf, Kim. 1998. "Advocacy in the Guise of Science: How Preliminary Research on the Cleveland Voucher Program Was 'Reanalyzed' to Fit a Preconception." Education Week 18(3): 34, 39.

Muir, Edward. 1999. "They Blinded Me with Political Science: On the Use of NonpeerReviewed Research in Education Policy." PS: Political Science and Politics 32(December): 762-64.

Peterson, Paul. 1990. "Monopoly and Competition in American Education." In Choice and Control in American Education, Vol. 1, ed. William $\mathrm{H}$. Clune and John F. Witte. New York: Falmer Press.
Peterson, Paul, and Jay Greene. 1996. "School Choice Data Rescued from Bad Science." The Wall Street Journal, August 14.

Peterson, Paul, and Chad Noyes. 1996. "Under Extreme Duress, School Choice Success" <http://data.fas.harvard.edu/pepg/ index.htm>. Program on Educational Policy and Governance Research Paper. Accessed: February 18, 2000.

Putnam, Robert. 1997. "Bowling Alone: Democracy in America at Century's End." In Democracy's Victory and Crisis, ed. Alex Hadenius. New York: Cambridge University Press.
Rouse, Cecelia. 1998. "Private School Vouchers and Student Achievement: An Evaluation of the Milwaukee Parental Choice Program." The Quarerly Joumal of Economics 113(May): 553-602.

Witte, John. 1996. "A Reply to Greene, Peterson and Du: The Effectiveness of School Choice in Milwaukee: A Secondary Analysis of Data from the Program's Evaluation." Presented at the Annual Meeting of the American Political Science Association, San Francisco. 


\section{Take your students on a tour of one of the leading debates of our time \\ “...incredibly good.... I love the way that it is structured: giving people the range of choices on this complex matter is just the right approach." \\ -Dr. William Damon, director, Stanford University Center on Adolescence \\ Violent Kids: \\ Can We Change the Trend? \\ Violent Kids
Can We Change the Trend? \\ by Michael deCourcy Hinds}

Finally, a nonpartisan guide that sorts through the maze of facts, figures and theories from leading academics and social commentators and gives students the information they need to make up their own minds. What are the root causes of youth violence? Permissive parenting? Troubled family situations? A reckless media? What solutions will work? 